\title{
TINGKAT KEBUGARAN JASMANI PADA SISWA EKSTRAKURIKULER FUTSAL DI SMA NEGERI 1 TEGALWARU
}

\author{
Abdul Rohman ${ }^{1}$, Bambang Ismaya ${ }^{2}$, Fachrudin $^{3}$ \\ Universitas Singaperbangsa Karawang ${ }^{1,2,3}$ \\ E-mail: @student.unsika.ac.id
}

\begin{abstract}
ABSTRAK
Tujuan dari penelitian ini adalah untuk mengetahui Tingkat Kebugaran Jasmani Pada Siswa Ekstrakurikuler Futsal di SMAN 1 Tegalwaru. Penelitian ini merupakan penelitian deskriptif dalam bentuk data kuantitatif, Metode yang digunakan dalam penelitian ini adalah metode survey dengan menggunakan teknik sampling jenuh. Istilah lain dari sampel jenuh yaitu dimana seluruh anggota dijadikan sampel. Populasi dalam penelitian ini adalah semua siswa ekstrakurikuler Futsal di SMA Negeri 1 Tegalwaru yang berjumlah 28 siswa. Berdasarkan hasil penelitian, diperoleh bahwa 0 siswa $(0 \%)$ mempunyai tingkat kebugaran jasmani kurang sekali, 5 siswa (17,8\%) mempunyai tingkat kebugaran jasmani kurang, 15 siswa $(53,6 \%)$ mempunyai kemampuan tingkat kebugaran jasmani sedang , 8 siswa $(28,6 \%)$ mempunyai kemampuan tingkat kebugaran jasmani baik dan 0 siswa (0\%) mempunyai kemampuan tingkat kebugaran jasmani baik sekali. Melihat dari hasil tes tingkat kebugaran jasmani siswa ekstrakurikuler futsal SMA Negeri 1 Tegalwaru secara keseluruhan dapat disimpulkan bahwa kemampuan tingkat kebugaran jasmani siswa dengan rata-rata dalam kategori sedang yaitu dalam kategori kurang 5 siswa (17,8\%), mempunyai tingkat kebugaran jasmani dalam kategori sedang 15 siswa $(53,6 \%)$, dan mempunyai kemampuan tingkat kebugaran jasmani dalam kategori baik 8 siswa $(28,6 \%)$.
\end{abstract}

Kata Kunci: Kebugaran Jasmani

\begin{abstract}
The purpose of this study was to determine the level of physical fitness in Futsal extracurricular students at SMAN 1 Tegalwaru. This research is a descriptive research in the form of quantitative data. The method used in this research is a survey method using saturated sampling technique. Another term for saturated sample is where all members are sampled. The population in this study were all Futsal extracurricular students at SMA Negeri 1 Tegalwaru, totaling 28 students. Based on the results of the study, it was found that 0 students (0\%) had a very low level of physical fitness, 5 students (17.8\%) had a low level of physical fitness, 15 students (53.6\%) had a moderate level of physical fitness, 8 students (28.6\%) had a good level of physical fitness and 0 students $(0 \%)$ had a very good level of physical fitness. Seeing from the results of the physical fitness level test of futsal extracurricular students at SMA Negeri 1 Tegalwaru as a whole, it can be concluded that the average level of physical fitness of students in the medium category is in the category of less than 5 students (17.8\%), having a level of physical fitness in the category being 15 students (53.6\%), and having the ability level of physical fitness in the good category of 8 students $(28.6 \%)$.
\end{abstract}

Keywords: Physical Fitness.

Dipublikasikan Oleh :

UPT Publikasi dan Pengelolaan Jurnal

Universitas Islam Kalimantan Muhammad Arsyad Al-Banjari Banjarmasin 


\section{PENDAHULUAN}

Pendidikan jasmani olahraga dan kesehatan adalah mata pelajaran yang sangat penting untuk dipelajari siswa di masa sekarang ini, karena dengan pengetahuan mengenai kesehatan dan praktek olahraga siswa dapat membentengi diri salah satunya dengan meningkatkan daya tahan tubuh (imunitas) untuk mencegah corona virus. Dengan olahraga teratur menjadi salah satu cara untuk menjaga kesehatan. Pendidikan jasmani merupakan kebutuhan bagi peserta didik, Di dalamnya pendidikan pembelajaran pendidikan jasmani dapat belajar sambil bergembira melalui penyaluran hasratnya untuk bergerak, apalagi ditunjang dengan penggunaan peralatan. Semakin terpenuhi kebutuhan akan gerak dalam masa pertumbuhannya, makin besar dampaknya bagi kualitas pertumbuhan itu sendiri. Sebagai mana telah di sampaikan Rink "Arti pendidikan jasmani adalah pendidikan melalui fisikal. Kontribusi unik pendidikan jasmani terhadap pendidikan secara umum adalah perkembangan tubuh secara menyeluruh melalui kegiatan jasmani” (Mingseli, 2020). Merujuk pada Peraturan Menteri Pendidikan dan Kebudayaan Republik Indonesia Nomor 62 tahun 2014 tentang Kegiatan Ekstrakurikuler Pada Pendidikan Dasar dan Pendidikan Menengah, ekstrakurikuler adalah kegiatan pengembangan karakter dalam rangka perluasan potensi, bakat, minat, kemampuan, kepribadian, kerja sama, dan kemandirian peserta didik secara optimal yang dilakukan di luar jam belajar kegiatan intrakurikuler dan kegiatan kokurikuler di bawah bimbingan dan pengawasan satuan pendidikan (Dikdas \& Dikmen Kementrian Pendidikann, 2020).

Maka dari itu satuan pendidikan memiliki kewajiban untuk menyelenggarakan kegiatan ekstrakurikuler sebagai wahana memfasilitasi pengembangan bakat dan minat peserta didik. Karena "adanya potensi yang bagus bila mana tidak dilatih dengan latihan yang rutin, maka potensi itu bukan tidak mungkin akan hilang dari dalam diri individu tersebut" (Abdullah waffa, Safei, \& Bambang Ismaya, 2020). Diberlakukan nya Pembatasan Sosial Berskala Besar (PSBB) untuk memutus rantai penyebaran Covid-19 mengharuskan guru, melaksanakan WFH (work from home) dalam melaksanakan tugasnya sebagai pendidik. Kondisi kegiatan pengajaran yang tiba-tiba berubah drastis ini menjadi tantangan bagi guru khususnya guru pendidikan jasmani olahraga dan kesehatan (PJOK), agar sasaran dan tujuan pendidikan jasmani olahraga dan kesehatan dapat tercapai. "Melalui surat edaran Mendikbud no 4 Tahun 2020 terkait panduan pembelajaran di rumah selama masa pandemic mengharuskan guru untuk tidak membebani peserta didik melalui tuntutan capaian kurikulum sebagai syarat kenaikan kelas" (Saefuloh Asep, 2020).

Sebagaimana dari pernyataan di atas dapat di simpulkan pentingnya terlaksananya pembelajaran penjas atau yang di sebut dengan PJOK (Pendidikan Jasmani Kesehatan dan Olahraga) Selain membantu mengembangkan dan meningkatkan potensi siswa dalam bidang olahraga terutama kebugaran jasmani penjas sendiri juga menjelaskan tentang pentingnya cara hidup sehat. Dengan begitu pelatih memutuskan untuk merubah porsi latihan, tentunya dengan jadwal latihan sedikit berubah dengan peserta di bagi 2 tim untuk mengurangi kerumunan lalu jadwal latihan Tim (A) yang berjumlah 14 peserta hari senin dan rabu dengan porsi yang berbeda tentunya yang biasanya sebelum pandemic latihan bisa minimal 3 jam menjadi kurang dari 2 jam di masa pandemic. 'Kebugaran jasmani dapat diperoleh dengan cara berolahraga, oleh karena itu olahraga dapat di jadikan sebagai bagian dari kehidupan sehingga tidak salah apabila tubuh tidak aktif bergerak maka jangan harap kondisi fisik menjadi tetap optimal dan segar'. Di perkuat dengan Sumber (Kemendikbud.2013:169-170 (Abu Hasan Al Jamil, 2018)).

Pentingnya bagi siswa ekstrakurikuler futsal di SMA Negeri 1 Tegalwaru agar selalu tetap menjaga kondisi tubuhnya dengan berolahraga secara mandiri dan teratur di luar jadwal latihan ekstrakurikuler futsal. Hal itu dilakukan untuk menjaga kebugaran jasmani atau bisa di sebut dengan daya tahan tubuh, agar pada saat latihan kembali normal, siswa ekstrakurikuler futsal tidak mengalami kelelahan yang berarti. Selain itu, ekstrakurikuler futsal di SMA Negeri 1 Tegalwaru belum memiliki catatan kebugaran jasmani setiap anggotanya, maka dari itu peneliti tertarik dan bertujuan melakukan tes kebugaran jasmani untuk mengetahui Tingkat Kebugaran Jasmani Siswa Pada Ekstrakurikuler Futsal di SMA Negeri 1 Tegalwaru.

\section{METODE}

Desain penelitian ini merupakan penelitian deskriptif kuantitatif, dalam penelitian ini menggambarkan tentang keadaan tingkat kebugaran siswa yang mengikuti ekstrakurikuler futsal di SMAN 1 Tegalwaru. Berdasarkan sifat masalahnya teknik pengumpulan data menggunakan survey melalui teknik sampling jenuh (sensus).

Dipublikasikan Oleh :

UPT Publikasi dan Pengelolaan Jurnal

Universitas Islam Kalimantan Muhammad Arsyad Al-Banjari Banjarmasin 


\section{Instrumen Penelitian}

Menurut (Suharmi Arikunto, 2010) "instrumen penelitian adalah alat bantu yang dipilih dan digunakan oleh peneliti dalam kegiatannya mengumpulkan agar kegiatan tersebut menjadi sistematis dan dipermudah olehnya". Instrumen yang di gunakan pada penelitian ini yaitu alat ukur yang digunakan memiliki validitas dan reliabilitas yang baik. Alat ukur dirancang agar dapat menghasilkan keakuratan suatu data sesuai dengan data yang diperlukan. Di Indonesia sendiri ada tingkat standarnya sekaligus di gunakan dalam penelitian ini, yaitu Tes Kebugaran Jasmani Indonesia (TKJI) untuk umur 16-19 tahun yang meliputi: (1) Lari 60 meter (sprint), (2) Angkat Tubuh (full up) 60 detik, (3) Baring Duduk (sit up) 60 detik, (4) Loncat Tegak (vertical jump), (5) Lari 1200 meter berperan sebagai instrumen yang cocok atau sesuai karena tes ini sudah distandarkan sesuai standar Nasional.

Table 1 Nilai Tes Kebugaran Jasmani Indonesia (TKJI) untuk umur 16-19 tahun

\begin{tabular}{|c|c|c|c|c|c|}
\hline Sprint $60 \mathrm{M}$ & $\begin{array}{ll}\text { Pull } & U p(60 \\
\text { Detik) } & \end{array}$ & $\begin{array}{ll}\text { Sit } U p( & 60 \\
\text { Detik } & \end{array}$ & Vertical Jump & Lari $1200 \mathrm{M}$ & Nilai \\
\hline S.d-7,2" & 19-keatas & 41-keatas & 73-keatas & s.d-3,14" & 5 \\
\hline $7,3 "-8,3 "$ & 14-18 & $30-40$ & $60-72$ & $3,15 "-4,23 ”$ & 4 \\
\hline $8,4 "-9,6 "$ & $9-13$ & $21-29$ & $50-59$ & $4,24 "-5,12 "$ & 3 \\
\hline $9,7 "-11,0 "$ & $5-8$ & $10-20$ & $39-49$ & $5,13 "-6,33 "$ & 2 \\
\hline $11,1-d s t$ & $0-4$ & $0-9$ & $0-38$ & 6,34 "'dst & 1 \\
\hline
\end{tabular}

\section{POPULASI DAN SAMPLE}

Menurut (Sugiyono 2015:80)"dalam bukunya menjelaskan bahwa populasi adalah wilayah generalisasi yang terdiri atas: obyek/subyek yang mempunyai kualitas dan karakteristik tertentu yang ditetapkan oleh peneliti untuk dipelajari dan kemudian ditarik kesimpulan nya". Populasi dalam penelitian ini adalah semua siswa ekstrakurikuler Futsal di SMA Negeri 1 Tegalwaru. Menurut (Sugiyono 2015:81) sampel adalah bagian dari jumlah dan karakteristik yang dimiliki oleh populasi. Teknik yang digunakan yaitu Total Sampling Jenuh, yaitu peneliti mengambil keseluruhan populasi untuk dijadikan sampel. Seluruh anggota (populasi) diambil sebagai sampel karena peneliti menganggap bahwa seluruh anggota memiliki informasi yang diperlukan bagi penelitiannya. Sehingga dengan demikian sampel pada penelitian ini adalah semua siswa ekstrakurikuler futsal di SMA Negeri 1 Tegalwaru yang berjumlah 28 orang.

\section{ANALISIS DATA}

Analisis data ini perlu untuk memperoleh data awal dari hasil tes kondisi fisik, peneliti mengacu pada standar penilaian menurut (Tes Kesegaran Jasmani Indonesia) Kriteria penilaian yang aka digunakan mengacu pada norma-norma yang telah dipakai untuk memberikan nilai-nilai dari setiap skor butir-butir, dengan kategori (1) baik sekali, (2) baik, (3) sedang, (4) kurang, (5) kurang sekali. Konversi nilai dari setiap kategori adalah sebagai berikut :

Table 2 Norma Tes Kesegaran Jasmani

\begin{tabular}{|l|l|l|l|}
\hline No & $\begin{array}{l}\text { Konversi } \\
\text { Nilai }\end{array}$ & $\begin{array}{l}\text { Jumlah } \\
\text { Nilai }\end{array}$ & Klasifikasi \\
\hline 1. & 5 & $22-25$ & $\begin{array}{l}\text { Baik Sekali } \\
\text { (BS) }\end{array}$ \\
\hline 2. & 4 & $18-21$ & Baik (B) \\
\hline 3. & 3 & $14-17$ & Sedang (S) \\
\hline 4. & 2 & $10-13$ & Kurang (K) \\
\hline 5. & 1 & $5-9$ & $\begin{array}{l}\text { Kurang Sekali } \\
\text { (KS) }\end{array}$ \\
\hline
\end{tabular}

Setelah didapat data kemudian data tersebut akan dianalisis, sehingga hasil yang diperoleh bisa mendeskripsikan tingkat kebugaran jasmani pada siswa ekstrakurikuler futsal di SMA Negeri 1 Tegalwaru, "Kemudian hasil yang terdapat dalam kategori norma tes kebugaran jasmani indonesia dilakukan analisis deskriptif melalui persentase yang digunakan adalah sebagai berikut”: (Sudijono Anas, 2011). 
Rumus Persentase

$P=\frac{F}{N} \times 100 \%$

Keterangan :

$\mathrm{P}=$ Angka Persentase

$\mathrm{N}=$ Jumlah frekuensi/banyaknya individu.

\section{HASIL DAN PEMBAHASAN}

1. Tes Lari 60 Meter (Sprint)

Hasil dari tes kecepatan lari 60 meter berpacu kepada standar TKJI (Tes Kebugaran Jasmani Indonesia) dengan perolehan nilai yang dikategorikan menjadi lima kategori yaitu, baik sekali, baik, sedang, kurang, dan kurang sekali. Dibawah ini merupakan tabel distribusi frekuensi hasil tes lari 60 meter tingkat kebugaran jasmani siswa ekstrakurikuler futsal di SMA Negeri 1 Tegalwaru, Sebagai Berikut :

Tabel 1 Klasifikasi Tes Lari 60 Meter

\begin{tabular}{|c|c|c|c|c|}
\hline No & Skor & Kategori & $\begin{array}{ll} & \text { Frekuen } \\
\text { si } & \\
\end{array}$ & ntase $\%$ \\
\hline 1. & 5 & Baik Sekali (BS) & 12 & $\% \quad 42,9$ \\
\hline 2. & 4 & Baik (B) & 10 & $\%$ \\
\hline 3. & 3 & Sedang (S) & 3 & $\begin{array}{ll}\% & 10,7\end{array}$ \\
\hline 4. & 2 & Kurang (K) & 3 & $\%$ \\
\hline 5. & 1 & Kurang Sekali (KS) & 0 & 0 \\
\hline & & & 28 & $100 \%$ \\
\hline
\end{tabular}

Keterangan : Kajian Peneliti

Gambar 1 Klasifikasi Tes Lari 60 Meter

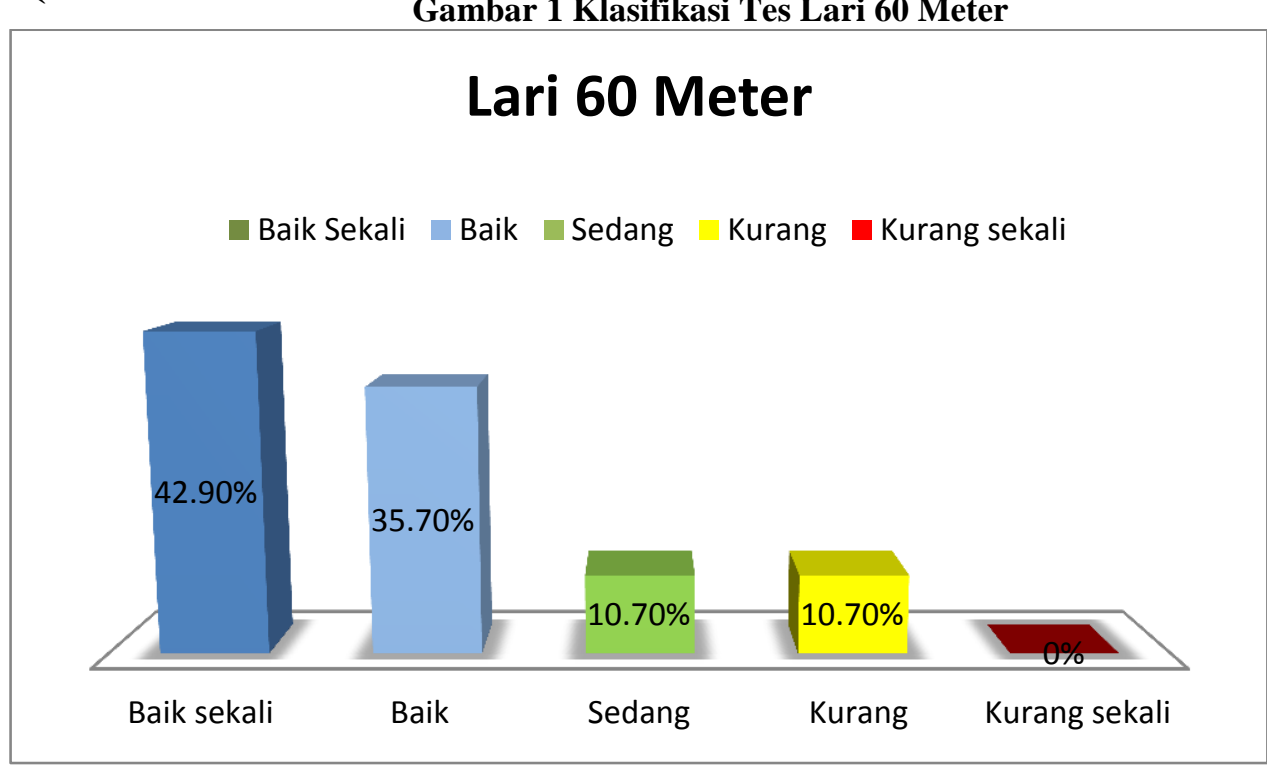

Sumber : Kajian Peneliti

Berdasarkan tabel dan gambar di atas, diperoleh bahwa 0 siswa $(0 \%)$ mempunyai kecepatan lari kurang sekali, 3 siswa (10,7\%) mempunyai kecepatan lari kurang, 3 siswa $(10,7 \%)$ mempunyai kecepatan lari Sedang , 10 siswa $(35,7 \%)$ mempunyai kecepatan lari baik dan 12 siswa (42,9\%) mempunyai kecepatan lari baik sekali.

Dipublikasikan Oleh :

UPT Publikasi dan Pengelolaan Jurnal

Universitas Islam Kalimantan Muhammad Arsyad Al-Banjari Banjarmasin 


\section{2. $\quad$ Tes Gantung Siku Tekuk (Full Up 60 Detik)}

Hasil dari tes ful up 60 detik berpacu kepada standar TKJI (Tes Kebugaran Jasmani Indonesia) dengan perolehan nilai yang dikategorikan menjadi lima kategori yaitu, baik sekali, baik, sedang, kurang, dan kurang sekali. Dibawah ini merupakan tabel distribusi frekuensi hasil tes full up 60 detik tingkat kebugaran jasmani siswa ekstrakurikuler futsal di SMA Negeri 1 Tegalwaru, Sebagai Berikut:

Tabel 4 Tabel Klasifikasi Tes Full Up

\begin{tabular}{|l|c|l|c|c|}
\hline No & Skor & Kategori & Frekuens & Persen \\
\hline 1. & 5 & Baik Sekali (BS) & 0 & 0 \\
\hline 2. & 4 & Baik (B) & 2 & $7,1 \%$ \\
\hline 3. & 3 & Sedang (S) & 4 & $14,3 \%$ \\
\hline 4. & 2 & Kurang (K) & 5 & $17,9 \%$ \\
\hline 5. & 1 & Kurang Sekali (KS) & 17 & $60,7 \%$ \\
\hline \multicolumn{2}{|r|}{ Total } \\
\hline
\end{tabular}

Keterangan : Kajian Peneliti

Gambar 2 Klasifikasi Tes Full $U p$

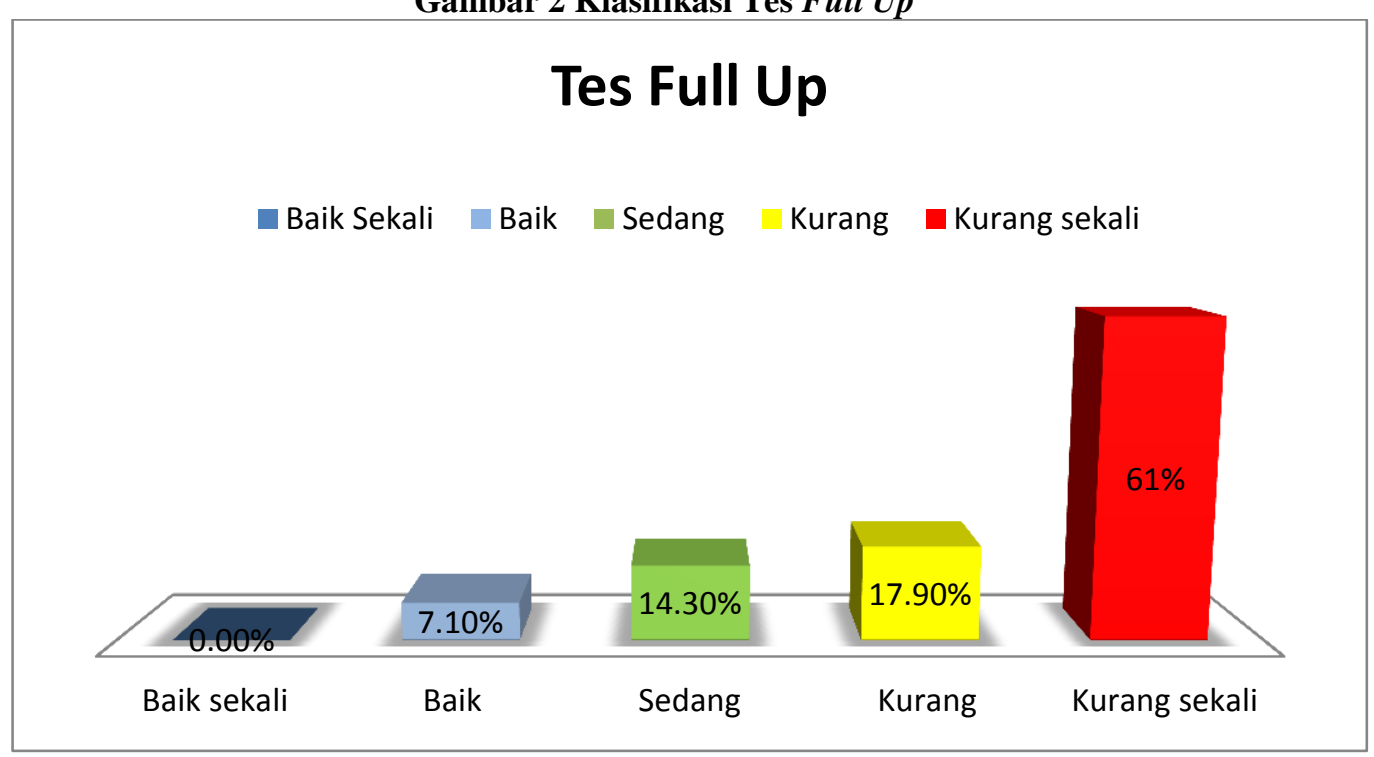

\section{Sumber : Kajian Peneliti}

Berdasarkan tabel dan gambar di atas, diperoleh bahwa 17 siswa (60,7\%) mempunyai kemampuan full up kurang sekali, 5 siswa (17,9\%) mempunyai kemampuan full up kurang, 4 siswa (14,3\%) mempunyai kemampuan full up Sedang , 2 siswa $(7,1 \%)$ mempunyai kemampuan full up baik dan 0 siswa (0\%) mempunyai kemampuan full up baik sekali.

Dipublikasikan Oleh :

UPT Publikasi dan Pengelolaan Jurnal

Universitas Islam Kalimantan Muhammad Arsyad Al-Banjari Banjarmasin 


\section{3. $\quad$ Tes Baring Duduk (Sit Up 60 Detik)}

Hasil dari tes sit up 60 detik berpacu kepada standar TKJI (Tes Kebugaran Jasmani Indonesia) dengan perolehan nilai yang dikategorikan menjadi lima kategori yaitu, baik sekali, baik, sedang, kurang, dan kurang sekali. Dibawah ini merupakan tabel distribusi frekuensi hasil tes sit up 60 detik tingkat kebugaran jasmani siswa ekstrakurikuler futsal di SMA Negeri 1 Tegalwaru, Sebagai Berikut:

Tabel 2 Klasifikasi Tes Sit Up

\begin{tabular}{|l|c|c|c|c|}
\hline No & Skor & Kategori & si & Prekuen \\
\hline 1. & 5 & Baik Sekali (BS) & 21 & $75 \%$ \\
\hline 2. & 4 & Baik (B) & 7 & $25 \%$ \\
\hline 3. & 3 & Sedang (S) & 0 & 0 \\
\hline 4. & 2 & Kurang (K) & 0 & 0 \\
\hline 5. & 1 & Kurang Sekali (KS) & 0 & 0 \\
\hline \multicolumn{2}{|c|}{ Total }
\end{tabular}

Keterangan : Kajian Peneliti

Gambar 3 Klasifikasi Tes Sit Up

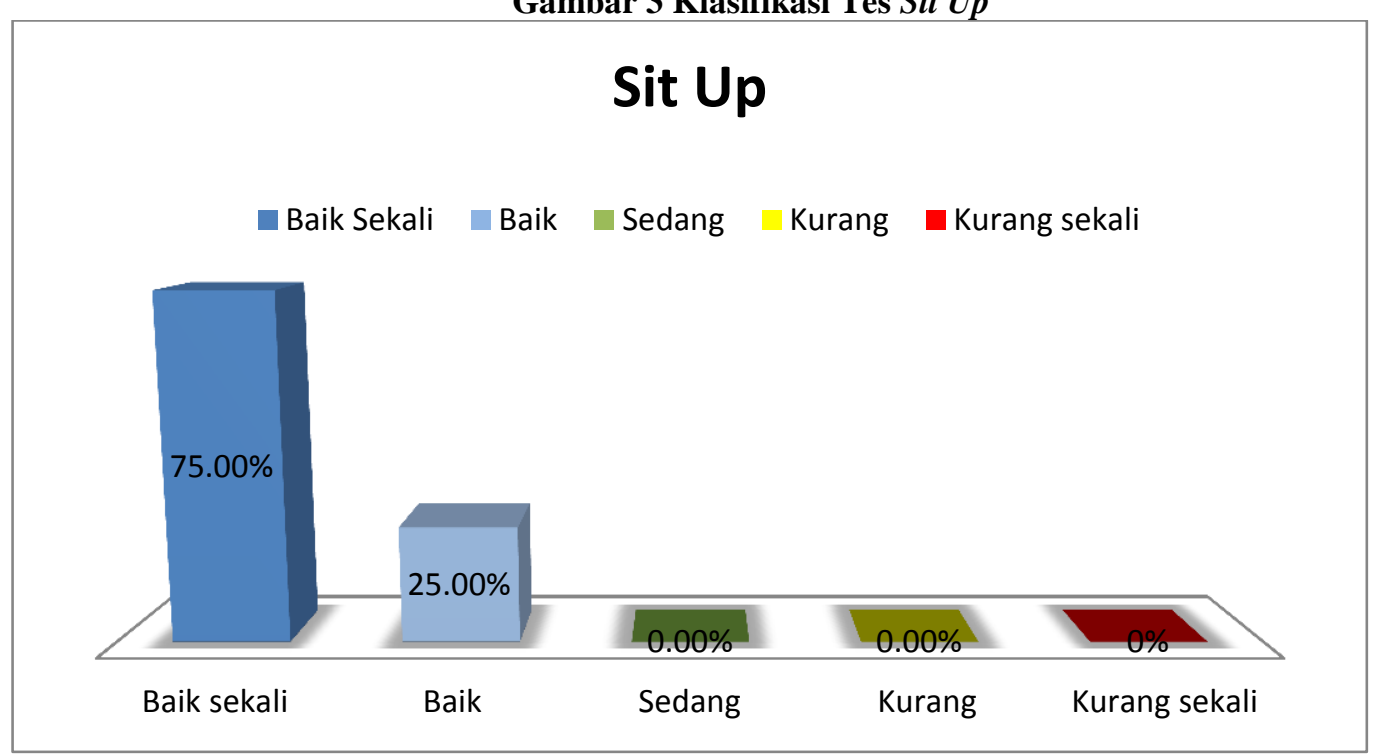

\section{Sumber : Kajian Peneliti}

Berdasarkan tabel dan gambar di atas, diperoleh bahwa 0 siswa $(0 \%)$ mempunyai kemampuan sit up kurang sekali, 0 siswa (0\%) mempunyai kemampuan sit up, 0 siswa (0\%) mempunyai kemampuan sitl up Sedang , 7 siswa (25\%) mempunyai kemampuan sit up baik dan 21 siswa (75\%) mempunyai kemampuan sit up baik sekali.

4. Tes Loncat Tegak (Tes Vertical Jump)

Hasil dari tes vertical jump berpacu kepada standar TKJI (Tes Kebugaran Jasmani Indonesia) dengan perolehan nilai yang dikategorikan menjadi lima kategori yaitu, baik sekali, baik, sedang, kurang, dan kurang sekali. Dibawah ini merupakan tabel distribusi frekuensi hasil tes vertical jump tingkat kebugaran jasmani siswa ekstrakurikuler futsal di SMA Negeri 1 Tegalwaru, Sebagai Berikut:

Tabel 6 Klasifikasi Tes Vertical Jump

\begin{tabular}{|c|c|c|c|c|}
\hline No & Skor & Kategori & si $\quad$ Frekuen & Perse \\
\hline
\end{tabular}

Dipublikasikan Oleh :

UPT Publikasi dan Pengelolaan Jurnal

Universitas Islam Kalimantan Muhammad Arsyad Al-Banjari Banjarmasin 


\begin{tabular}{|l|c|c|c|c|}
\hline 1. & 5 & Baik Sekali (BS) & 0 & \multicolumn{2}{|c|}{0} \\
\hline 2. & 4 & Baik (B) & 0 & \\
\hline 3. & 3 & Sedang (S) & 20 & $\%$ \\
\hline 4. & 2 & Kurang (K) & 8 & \multicolumn{2}{|c|}{0} \\
\hline 5. & 1 & Kurang Sekali (KS) & 0 & \multicolumn{2}{|c|}{$100 \%$} \\
\hline
\end{tabular}

\section{Keterangan : Kajian Peneliti}

Gambar 4 Klasifikasi Tes Vertical Jump

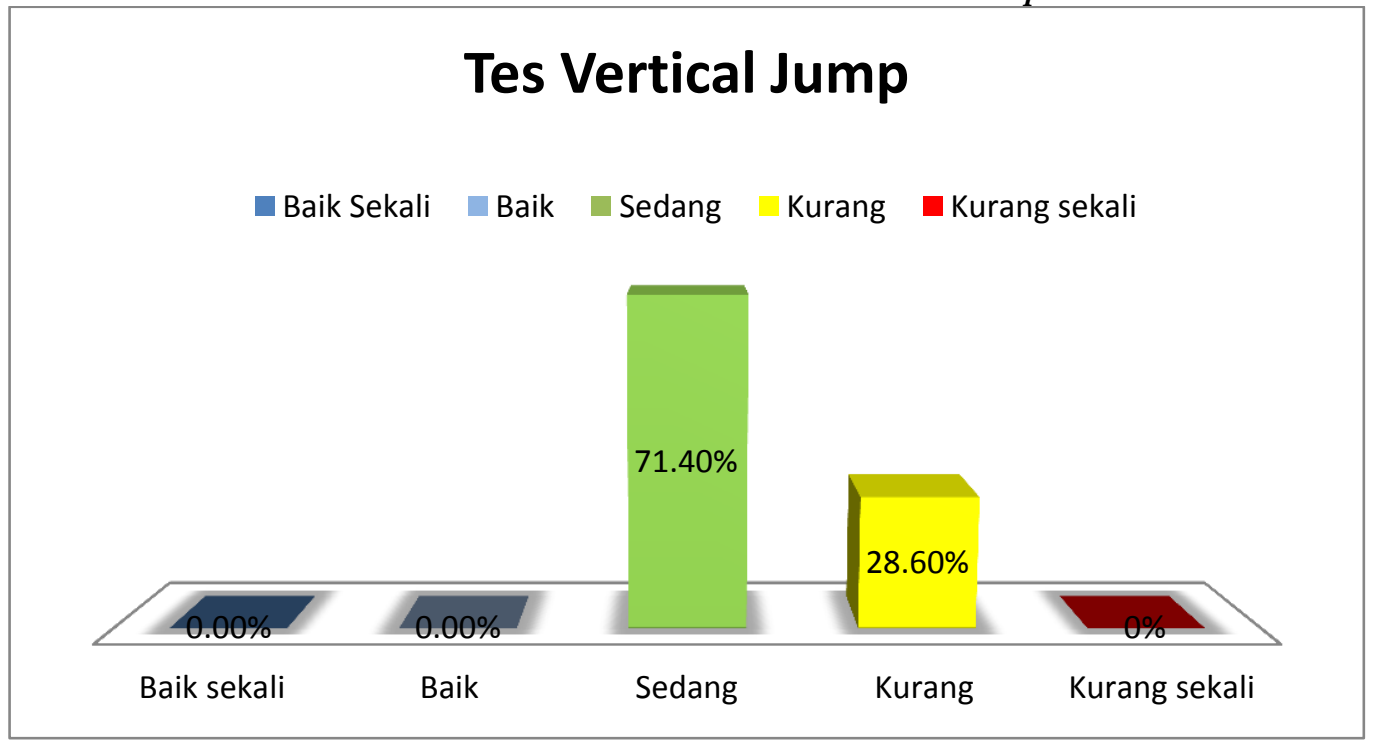

\section{Sumber : Kajian Peneliti}

Berdasarkan tabel dan gambar di atas, diperoleh bahwa 0 siswa $(0 \%)$ mempunyai kemampuan loncat tegak kurang sekali, 8 siswa $(28,6 \%)$ mempunyai kemampuan loncat tegak kuang, 20 siswa $(71.4 \%)$ mempunyai kemampuan loncat tegak Sedang , 0 siswa (0\%) mempunyai kemampuan loncat tegak baik dan 0 siswa $(0 \%)$ mempunyai kemampuan vertical jump baik sekali.

5. Tes Lari 1200 Meter

Hasil dari tes lari 1200 meter berpacu kepada standar TKJI (Tes Kebugaran Jasmani Indonesia) dengan perolehan nilai yang dikategorikan menjadi lima kategori yaitu, baik sekali, baik, sedang, kurang, dan kurang sekali. Dibawah ini merupakan tabel distribusi frekuensi hasil tes lari 1200 meter tingkat kebugaran jasmani siswa ekstrakurikuler futsal di SMA Negeri 1 Tegalwaru, Sebagai Berikut:

Dipublikasikan Oleh :

UPT Publikasi dan Pengelolaan Jurnal

Universitas Islam Kalimantan Muhammad Arsyad Al-Banjari Banjarmasin 
Tabel 3 Klasifikasi Tes Lari 1200 Meter

\begin{tabular}{|c|c|c|c|c|}
\hline No & Skor & Kategori & $\begin{array}{ll} & \text { Frekue } \\
\text { nsi } & \end{array}$ & $\begin{array}{l}\text { Perse } \\
\text { ntase } \%\end{array}$ \\
\hline 1. & 5 & Baik Sekali (BS) & 0 & 0 \\
\hline 2. & 4 & Baik (B) & 7 & $25 \%$ \\
\hline 3. & 3 & Sedang (S) & 11 & $\%$ \\
\hline 4. & 2 & Kurang (K) & 10 & $\%$ \\
\hline 5. & 1 & Kurang Sekali (KS) & 0 & 0 \\
\hline \multicolumn{3}{|c|}{ Total } & 28 & $\begin{array}{ll}\% & 100\end{array}$ \\
\hline
\end{tabular}

Keterangan : Kajian Peneliti

Gambar 5 Klasifikasi Tes Lari 1200 Meter

\section{Tes Lari 1200 Meter}

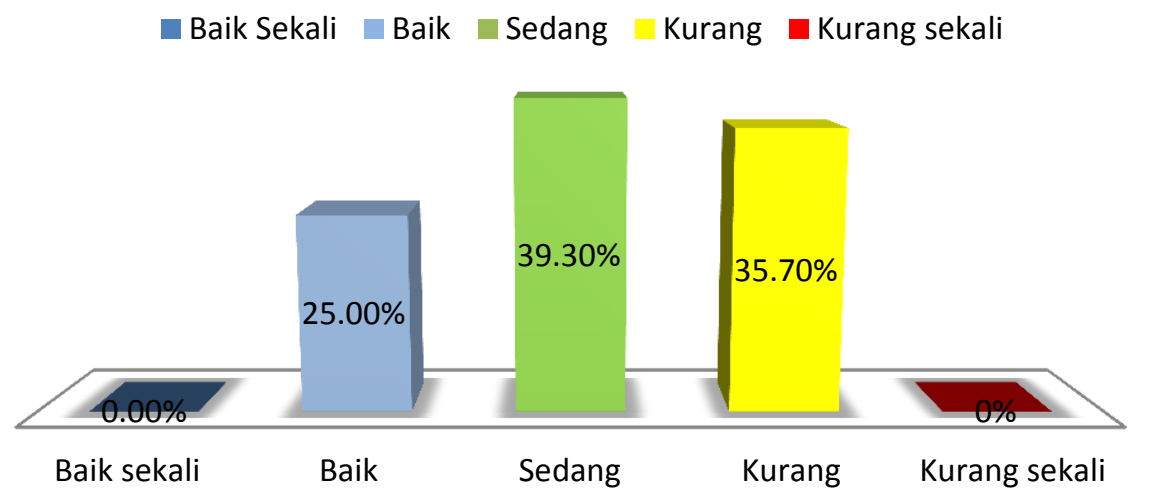

\section{Sumber : Kajian Peneliti}

Berdasarkan tabel dan gambar di atas, diperoleh bahwa 0 siswa $(0 \%)$ mempunyai kemampuan daya tahan kurang sekali, 10 siswa (35,7\%) mempunyai kemampuan daya tahan kurang, 11 siswa (39,3\%) mempunyai kemampuan daya tahan sedang , 7 siswa (25\%) mempunyai kemampuan daya tahan baik dan 0 siswa $(0 \%)$ mempunyai kemampuan daya tahan baik sekali.

6. Klasifikasi Hasil Tes Kebugaran Jasmani Siswa Ekstrakurikuler Futsal SMA Negeri 1 Tegalwaru.

Hasil dari tes kebugaran jasmani siswa berpacu kepada standar TKJI (Tes Kebugaran Jasmani Indonesia) dengan perolehan nilai yang dikategorikan menjadi lima kategori yaitu, baik sekali, baik, sedang, kurang, dan kurang sekali. Dibawah ini merupakan tabel distribusi frekuensi hasil tes tingkat kebugaran jasmani siswa ekstrakurikuler futsal di SMA Negeri 1 Tegalwaru, Sebagai Berikut:

Dipublikasikan Oleh :

UPT Publikasi dan Pengelolaan Jurnal

Universitas Islam Kalimantan Muhammad Arsyad Al-Banjari Banjarmasin 
Tabel 4 Klasifikasi Jumlah Nilai Tes Kebugaran Jasmani Siswa Ekstrakurikuler Futsal di SMA Negeri 1 Tegalwaru.

\begin{tabular}{|c|c|c|c|c|}
\hline No & $\begin{array}{ll}\text { Nilai } & \text { Jumlah } \\
\text { N }\end{array}$ & Kategori & $\begin{array}{ll} & \text { Frekuen } \\
\text { si } & \end{array}$ & ntase $\%$ \\
\hline 1. & $22-25$ & Baik Sekali (BS) & 0 & 0 \\
\hline 2. & $18-21$ & Baik (B) & 8 & $\%$ \\
\hline 3. & $14-17$ & Sedang (S) & 15 & $\%$ \\
\hline 4. & $10-13$ & Kurang (K) & 5 & $\%$ \\
\hline 5. & $5-9$ & $\begin{array}{lll} & \text { Kurang } & \text { Sekali } \\
(\mathrm{KS}) & & \\
\end{array}$ & 0 & 0 \\
\hline & Total & & 28 & $100 \%$ \\
\hline
\end{tabular}

Keterangan : Kajian Peneliti

Gambar 4.6 Klasifikasi Jumlah Nilai Tes Kebugaran Jasmani Siswa Ekstrakurikuler Futsal di SMA Negeri 1 Tegalwaru

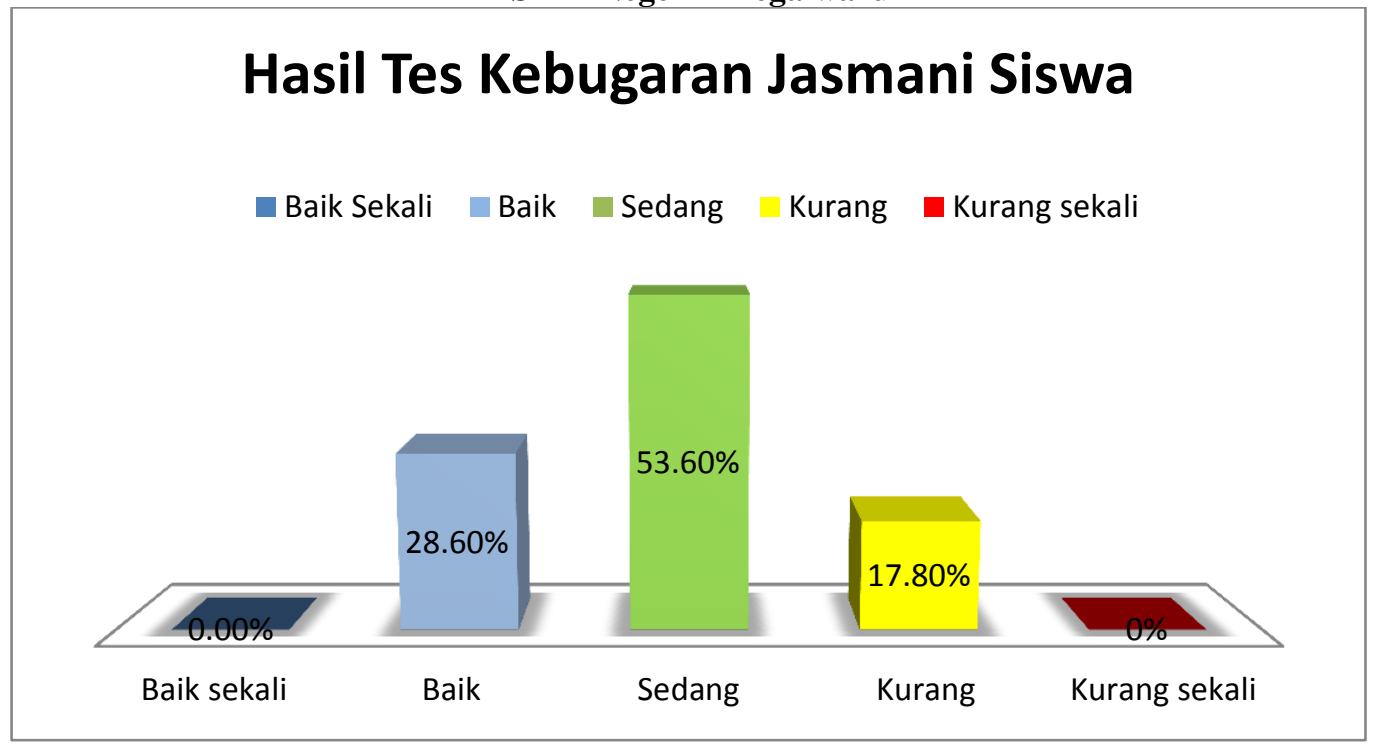

\section{Sumber : Kajian Peneliti}

Berdasarkan tabel dan gambar di atas, diperoleh bahwa 0 siswa $(0 \%)$ mempunyai tingkat kebugaran jasmani kurang sekali, 5 siswa (17,8\%) mempunyai tingkat kebugaran jasmani kurang, 15 siswa $(53,6 \%)$ mempunyai kemampuan tingkat kebugaran jasmani sedang , 8 siswa $(28,6 \%)$ mempunyai kemampuan tingkat kebugaran jasmani baik dan 0 siswa (0\%) mempunyai kemampuan tingkat kebugaran jasmani baik sekali.cSesuai yang tertulis pada latar belakang dalam penelitian ini, bahwa tujuan pada penelitian ini ingin mengetahui tingkat kebugaran jasmani siswa ekstrakurikuler futsal di SMA Negeri 1 Tegalwaru melalui TKJI dengan kategori batasan usia 16-19 tahun, dimana rata-rata usia pada siswa ini yaitu 16-17 tahun, dengan di dominasi usia 16 tahun yang berjumlah 17 siswa, sedangkan sisanya yang 17 tahun berjumlah 11 siswa. Dari hasil tes lari 60 meter didapatkan rata-rata nilai norma tes adalah 5 dalam kategori baik sekali (12 siswa), dari hasil tes full up selama 60 detik didapatkan rata-rata nilai norma tes adalah 1 dalam kategori kurang sekali (17 siswa), dari hasil tes sit up sela 60 detik didapatkan rata-rata nilai norma tes adalah 5 dalam kategori baik sekali (21 siswa), dari tes vertical jump didapatkan rata-rata nilai norma tes adalah 3 dalam kategori sedang (20 siswa), serta hasil dari tes lari 1200 meter didapatkan rata-rata nilai norma tes adalah 3 dalam kategori sedang (11 siswa). Demikian dapat disimpulkan bahwa hasil dari tes kebugaran jasmani siswa ekstrakurikuler futsal SMA

Dipublikasikan Oleh :

UPT Publikasi dan Pengelolaan Jurnal

Universitas Islam Kalimantan Muhammad Arsyad Al-Banjari Banjarmasin 
Negeri 1 Tegalwaru memilik rata-rata tingkat kebugaran jasmani dalam kategori Sedang (15 siswa). Berikut perhitungan persentase hasil dari keseluruhan tes beserta rumusnya :

1. Untuk kategori kurang terdapat 5 siswa.

$$
P=\frac{F}{N} \mathrm{x} 100 \%
$$

$P=\frac{5}{28} \times 100 \%$

$$
P=17,8 \%
$$

2. Untuk kategori sedang terdapat 15 siswa.

$P=\frac{15}{28} \times 100 \%$

$$
P=53,6 \%
$$

3. Untuk kategori baik terdapat 8 siswa.

$P=\frac{8}{28} \times 100 \%$

$$
P=53,6 \%
$$

Melihat dari hasil tingkat kebugaran jasmani siswa ekstrakurikuler futsal SMA Negeri 1 Tegalwaru secara keseluruhan menunjukkan kemampuan tingkat kebugaran jasmani siswa dengan rata-rata dalam kategori sedang bisa lebih berkembang tergantung terhadap pola latihan dan pola hidup siswa itu sendiri. Hasil dan pembahasan berisi hasil-hasil temuan penelitian dan pembahasannya. Tuliskan temuan-temuan yang diperoleh dari hasil-hasil penelitian yang telah dilakukan dan harus ditunjang oleh data-data yang memadai. Hasil-hasil penelitian dan temuan harus bisa menjawab pertanyaan atau hipotesis penelitian di bagian pendahuluan. Umumnya data-data hasil penelitian dapat dipaparkan menggunakan tabel. Contoh penggunaannya ditunjukkan pada tabel 1.

\section{PENUTUP}

Dapat disimpulkan dengan rincian dari hasil tes lari 60 meter didapatkan rata-rata nilai norma tes adalah 5 dalam kategori baik sekali (12 siswa), dari hasil tes full up selama 60 detik didapatkan rata-rata nilai norma tes adalah 1 dalam kategori kurang sekali (17 siswa), dari hasil tes sit up sela 60 detik didapatkan rata-rata nilai norma tes adalah 5 dalam kategori baik sekali ( 21 siswa), dari tes vertical jump didapatkan rata-rata nilai norma tes adalah 3 dalam kategori sedang ( 20 siswa), serta hasil dari tes lari 1200 meter didapatkan rata-rata nilai norma tes adalah 3 dalam kategori sedang (11 siswa). Melihat dari hasil tingkat kebugaran jasmani siswa ekstrakurikuler futsal SMA Negeri 1 Tegalwaru secara keseluruhan menunjukkan kemampuan tingkat kebugaran jasmani siswa dengan rata-rata dalam kategori sedang dengan rincian yang mempunyai tingkat kebugaran jasmani dalam kategori kurang 5 siswa $(17,8 \%)$, mempunyai tingkat kebugaran jasmani dalam kategori sedang 15 siswa (53,6\%), mempunyai kemampuan tingkat kebugaran jasmani dalam kategori baik 8 siswa $(28,6 \%)$, dan tidak ada siswa yang mempunyai tingkat kebugaran jasmani dalam kategori baik sekali dan kategori kurang sekali.

Dengan adanya permasalahan dan hasil pada penelitian ini, ada beberapa saran yang perlu penulis sampaikan yang berkaitan dengan penelitian ini.Bagi guru dan pelatih disarankan menerapkan pola latihan yang teratur dan terprogram, tidak hanya memfokuskan ke salah satu teknik permainan ataupun kondisi tingkat kebugaran jasmani siswa nya, melainkan harus diperhatikan keduanya karena teknik permainan akan lebih mudah dipelajari apabila siswa ditunjang dengan kemampuan tingkat kebugaran jasman yang baik, jika keduanya sama baiknya maka program dan tujuan latihan akan mudah di capai. Untuk siswa disarankan untuk selalu menjaga tingkat kebugaran jasmani dengan cara olahraga diluar jam latihan ekstrakurikuler futsal, dalam upaya meningkatkan kondisi tubuh, hindari pergaulan bebas, terapkan pola hidup sehat dan konsumsi makanan yang bergizi.

Dipublikasikan Oleh :

UPT Publikasi dan Pengelolaan Jurnal

Universitas Islam Kalimantan Muhammad Arsyad Al-Banjari Banjarmasin 


\section{REFERENSI}

Abdullah waffa, Safei, M. M., \& Bambang Ismaya. (2020). Pengaruh Model Pembelajaran Cooverative Learning Tipe Jigsaw Terhadap Keterampilan Dribbling Bola Basket Pada Siswa Kelas XI SMA Negeri 1 Rengasdengklok. Jurnal Literasi Olahraga, 1(1), 19-28.

Abu Hasan Al Jamil. (2018). Analisis Tingkat Kebugaran Jasmani Siswa Pendidikan Pondok Pesantren Di Kota Bengkulu. Ilmiah Pendidikan Jasmani, 2(1), 118-125.

Dikdas, \& Dikmen Kementrian Pendidikann. (2020). Ekstrakurikuler.

Mingseli. (2020). 18 Pengertian Pendidikan Jasmani Menurut Para Ahli.

Saefuloh Asep. (2020). PENJAS DIMASA PANDEMI.

Sudijono Anas. (2011). Pengantar Statistik Pendidikan. Jakarta: Rajawali Pers.

Sugiyono. (2015:80). Metode Penelitian Kuantitatif,Kualitatif Dan R \& D. Bandung: ALFABETA.

Sugiyono. (2015:81). Metode Penelitian Kuantitatif,Kualitatif Dan R \& D. Bandung: ALFABETA.

Suharmi Arikunto. (2010). Manajemen Penelitian. Jakarta: Rineka Cipta.Sutarman.

Dipublikasikan Oleh :

UPT Publikasi dan Pengelolaan Jurnal

Universitas Islam Kalimantan Muhammad Arsyad Al-Banjari Banjarmasin 